\title{
Wildlife Disease and Environmental Health in Alaska
}

Environmental health is defined by connections between the physical environment, ecological health, and human health. Current research within the U.S. Geological Survey (USGS) recognizes the importance of this integrated research philosophy, which includes study of disease and pollutants as they pertain to wildlife and humans. Due to its key geographic location and significant wildlife resources, Alaska is a critical area for future study of environmental health.

\section{Alaska as a Crossroads}

Alaska is an international crossroads for millions of migratory birds that journey each spring from wintering areas in Asia, South America, and Oceania. Populations of fish and marine mammals come to Alaska after migrating through Pacific and Arctic Oceans. These intercontinental migratory links could play an important role in the transmission of diseases that affect wildlife and humans. Key coastal areas offer breeding and stopover sites that are ideal settings for exchange of foreign and resident pathogens.

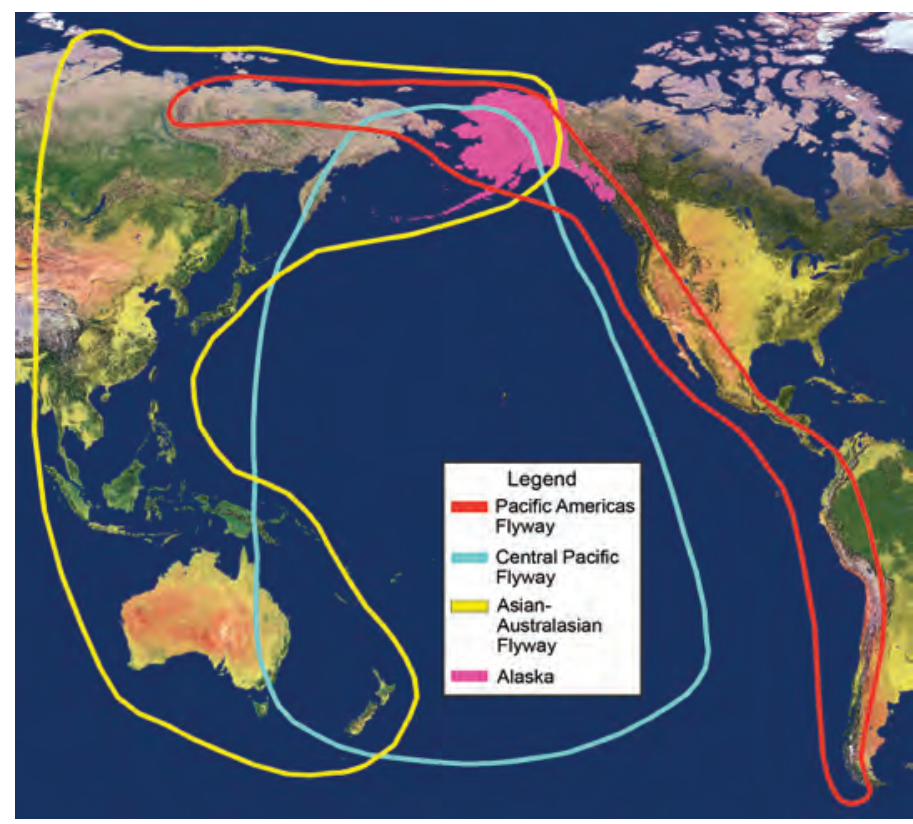

Alaska's position within migratory bird flyways of the Pacific Basin.

\section{Climate Change and Environmental Health}

Climate change is predicted to increase the distribution, spread, and virulence of some infectious diseases. Arctic environments face rapid and dramatic changes that include loss of sea ice, permafrost degradation, wetland drying, and related alterations in nutrient cycling. Pathogens in these areas are expected to respond quickly to new environmental challenges and opportunities. Additionally, the detection of relatively high levels of contaminants in the Arctic raises concern about the effects of local and global pollution on humans and wildlife. As a result, certain Arctic wildlife species have been recognized as valuable sentinels of anthropogenic change.

\section{Environmental health research at the Alaska Science Center focuses on}

- emerging wildlife diseases, particularly related to climate change;

- movement and transmission of wildlife pathogens; and

- demographic and fitness consequences of disease on wildlife populations.

Scientific information from this research is used to inform decision-making by wildlife management and human health agencies.

\section{The USGS Alaska Science Center}

With more than 30 years of ecological research in Arctic and sub-Arctic regions and a state-of-the-art molecular genetics facility, the Alaska Science Center is uniquely positioned to respond to new and existing issues in wildlife disease and environmental health. Long-term research and monitoring programs focus on a diversity of species including resident and migratory birds, caribou, fish, sea otters, polar bears, and walrus and provide important baseline information about the health of Alaskan wildlife. Ecological data are integrated with surveillance efforts to provide a better understanding of the connections between climate change, disease, and demographic impacts on wildlife populations. This information is valuable to community, state, and federal partners, such as the Climate, Ecosystems and Human Health Work Group, an inter-agency group that addresses the effects of climate change on human health in Alaska.

Black-capped chickadee with a deformed beak.

Photograph taken by John DeLapp.

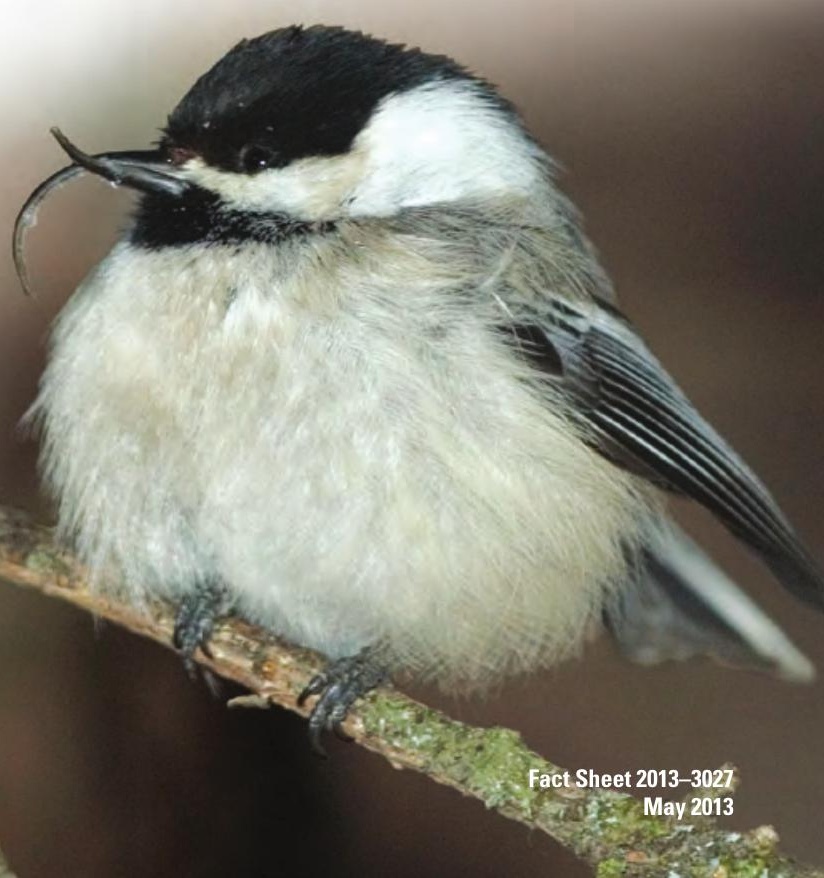




\section{Emerging Diseases and Climate Change}

\section{Infectious Disease}

High latitude regions are responding rapidly to climate warming and the resulting changes are expected to influence the spread of infectious diseases. Expanded ranges of host wildlife, shifts in phenology, and changes in environmental conditions may result in transfer of pathogens to new areas and to potentially naïve populations. Preliminary evidence suggests that changes in pathogen distribution and abundance in the Arctic are already underway. However, due in part to the remoteness of the area and its challenging environmental conditions, knowledge about wildlife disease in Alaska is limited. Scientists at the Alaska Science Center work in remote field locations throughout Alaska and have the opportunity to identify wildlife and environmental health issues as they emerge.

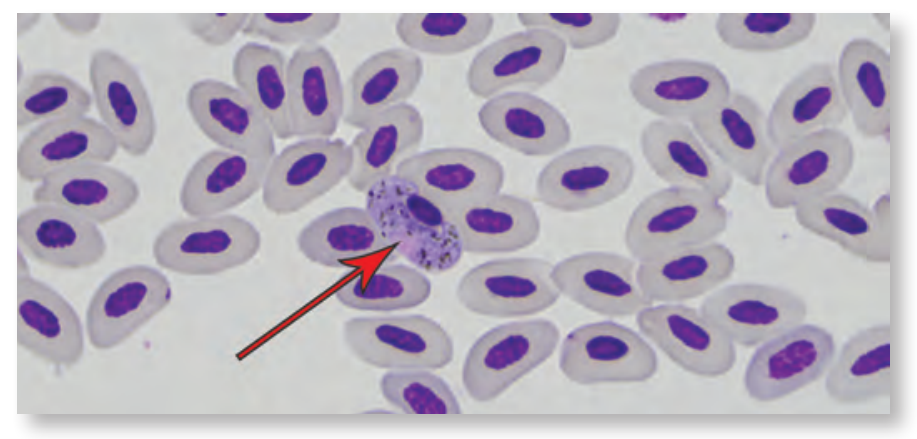

A mature blood parasite Haemoproteus nettionis.

\section{Environmental Contaminants}

Environmental contaminants threaten the health of wildlife and humans in the Arctic. Pollutants from lower latitude sources travel by large-scale atmospheric transport, driven by global wind and water currents, to the Arctic. Climate warming and increased anthropogenic activities, such as those related to mining and other natural resource extraction, may contribute to overall contaminant burdens. Some of these compounds persist in the environment for many years and accumulate in living organisms, especially in high trophic level predators like marine mammals. Contaminants in subsistence foods are of particular concern as many indigenous Alaskans rely on traditional sources of meat, fish, and berries. The Alaska Science Center is working with partners to measure levels of nutrients and contaminants in physical and biological samples and to evaluate potential effects on wildlife.
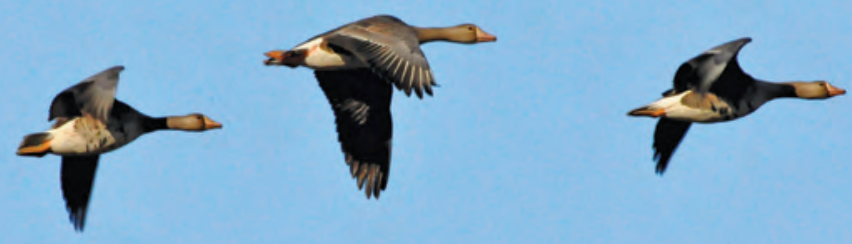

Greater white-fronted geese on the Arctic Coastal Plain.

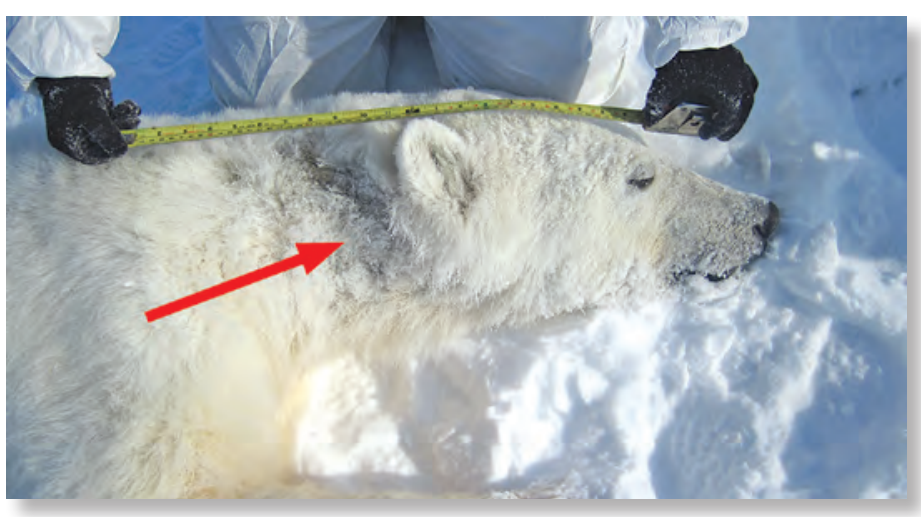

A polar bear with hair loss (alopecia) along its neck. The bear was captured by USGS scientists using the immobilizing drug Telazol.

\section{Selected Research at the Alaska Science Center}

- Avian keratin disorder was first detected among resident birds in Alaska in 1999. This debilitating condition is characterized by beak deformities and it affects a wide range of species. Current studies are investigating the causes and consequences of this emerging avian disease.

- Research on avian influenza has revealed important patterns of virus movement and transmission in migratory birds. Ongoing work includes surveillance for foreign-origin pathogens and study of intercontinental links between Asia and North America.

- Alopecia (loss of fur) and other skin lesions were recently observed in polar bears off the northern coast of Alaska. Biologists are examining samples from afflicted polar bears to identify possible causes of these lesions.

- Blood parasites (hematozoa), including avian malaria, infect resident and migratory bird species in Alaska. Current research is investigating whether blood parasites have deleterious effects on avian populations and if they are sensitive to changes in climate.

- As part of ongoing climate change research, biologists have observed a high rate of non-viable eggs in nests of greater white-fronted geese. Future analyses will provide insights about elevated rates of embryo mortality in birds and identify potentially pathogenic bacteria in a changing Arctic environment.

- Coxiella burnetii, a bacterial pathogen that causes disease in animals and humans, was recently detected in polar bears, northern fur seals, and soil samples in Alaska. Future studies will investigate the prevalence of this pathogen in marine and terrestrial species. 


\section{Movement and Transmission of Pathogens}

\section{Migration}

Both large- and small-scale animal movements have important implications for pathogen distribution. Research on the migration of waterfowl and other avian species plays a key role in evaluating potential routes of disease transport by wild birds. The emergence a highly pathogenic strain of H5N1 avian influenza virus that causes severe illness in birds and humans has heightened concerns about the potential role of wild birds in the transfer of disease between flyways. More than 2 million individuals of 94 species migrate to Alaska from Asia each spring. Recent studies by the Alaska Science Center demonstrated that migratory pathways of avian hosts could serve as links between H5N1 influenza outbreak sites in Asia and breeding areas of birds in Alaska. Waterfowl sampled in Alaska carried viruses with Asian-origin genes, and some of these viruses were transferred across multiple species.

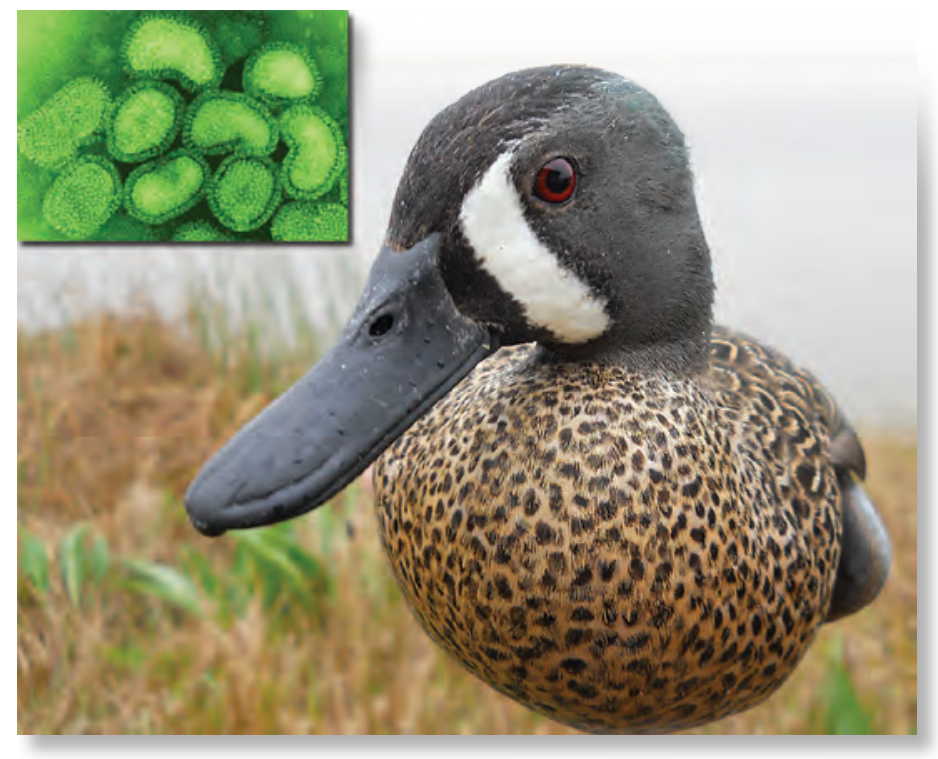

Blue-winged teal in Texas. Inset shows avian influenza virus.

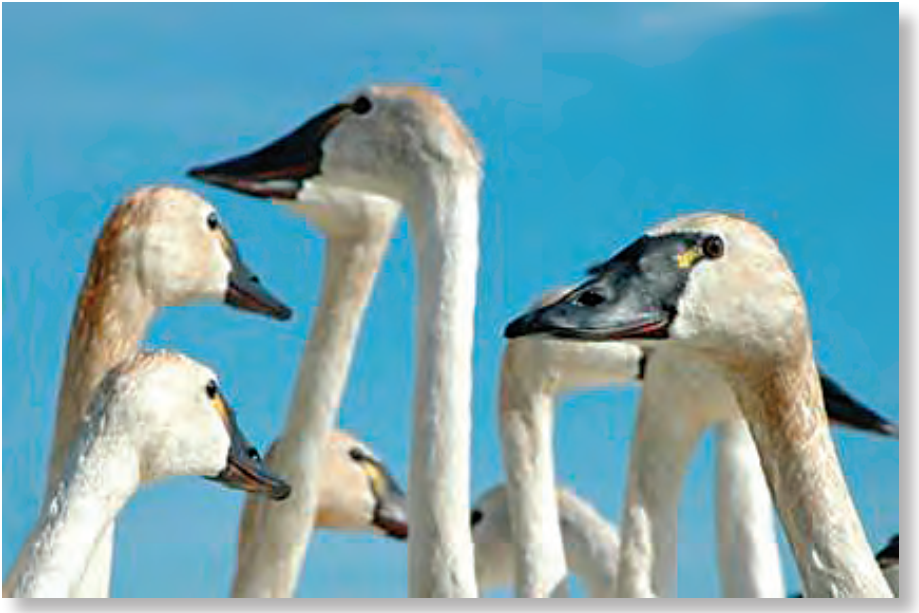

Tundra swans on Alaskan breeding grounds.

Research also has demonstrated that low-pathogenic strains of avian influenza viruses may overwinter in Alaskan wetlands and therefore be available to re-infect bird populations in subsequent years through consumption of virus-contaminated water. The Alaska Science Center is studying the detectability and persistence of avian influenza viruses in natural water systems of Alaska during winter and summer months. Additionally, experiments are underway to test the ability of filter-feeding invertebrates - common food for water birds - to accumulate viable virus and to act as potential disease vectors to avian hosts.

Certain "hot spots," including in western Alaska, have been identified as important surveillance locations to sample for diseases that might be introduced from Asia and then transferred to other locations. For example, avian influenza and Newcastle disease virus were detected in numerous species of waterfowl in Alaska and genetic analysis of isolates has implicated redistribution of these viruses by migratory birds. Research by the Alaska Science Center has recently expanded to include study of viruses in Neotropical migrants that provide connections between North, Central, and South America.

\section{Transition Zones: New Opportunities for Disease Transmission?}

Certain landscape features, such as those unique to the Arctic coastline, provide critical ecological transition zones that also may influence patterns of disease transmission. The intersection between sea water, sea ice, terrestrial land mass, and fresh water from major river deltas draws a diverse assemblage of species. Overlap in these environments creates an opportunity for pathogen exchange between primarily marine hosts (like polar bears, seals, and walruses) and terrestrial hosts (like caribou, gulls, foxes, and grizzly bears). Changing environmental conditions, primarily the loss of sea ice, has resulted in larger aggregations of birds and mammals on land, forcing more frequent encounters between historically segregated species or populations. Future investigations will target potential exchange of pathogens between marine and terrestrial hosts at these transition zones.

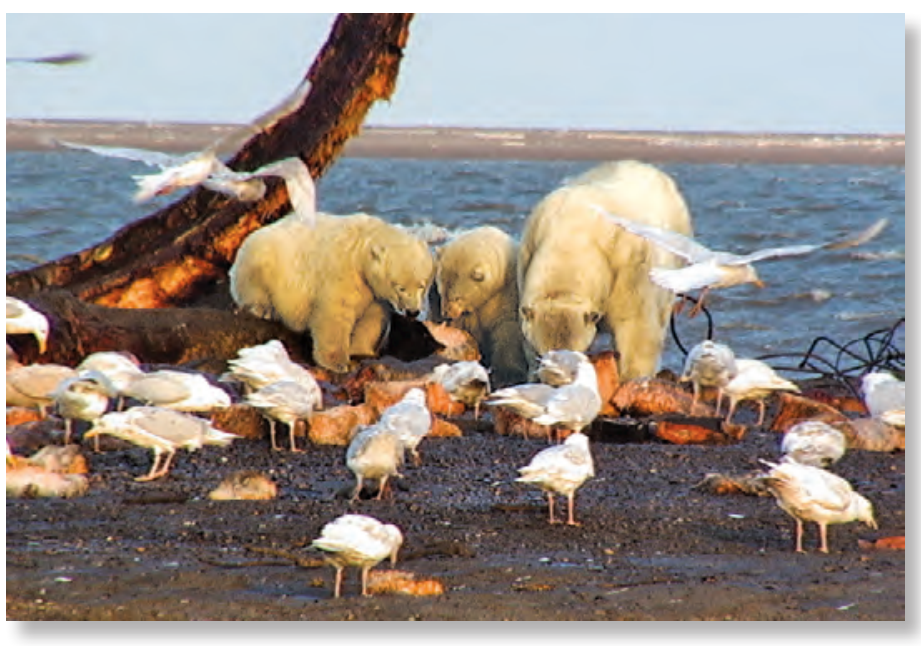

Polar bears and gulls feed on a whale carcass on the Arctic coast of Alaska. This is a possible transition zone for disease transmission. 


\section{Demographic and Fitness Consequences of Disease}

Fitness consequences of disease are presumed for wild animals, but are often difficult to quantify because sick individuals must be identified and then tracked over time to assess condition. The Alaska Science Center is conducting long-term studies that will allow an assessment of disease consequences on individual animals. For example, one current study addresses the influence of blood parasites on body condition of resident and migratory species during breeding and wintering seasons.

Quantifying the demographic impacts of wildlife diseases also will provide a more accurate assessment of other mortality factors (for example, hunting or environmental stressors associated with climate change) that could be important for management actions. An ongoing study of emperor geese in Western Alaska allows for detailed investigation of the effects of blood parasites on specific fitness parameters, including reproductive

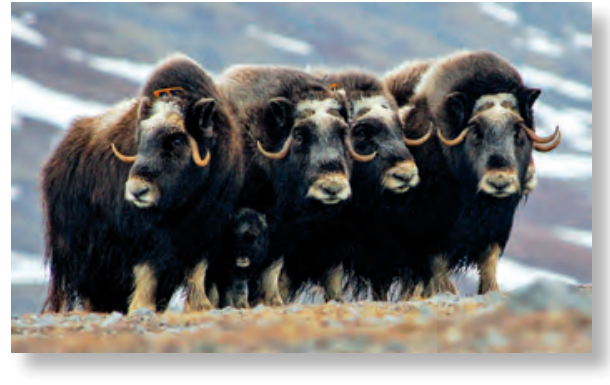

Muskoxen in northwestern Alaska. success and adult survival. If the rates of infection by blood parasites vary among years in relation to phenology, progressive climate change may cause changes in vulnerability to blood parasites.

In another study, the Alaska Science Center has documented surprisingly high mortality (20-30 percent) of adult female musk ox during mid- to late summer in northwestern Alaska. Given the magnitude and timing of the observed mortality, and the fact that these muskoxen are in good nutritional condition in late winter, a pathogen is suspected to be contributing to the high losses observed. Additionally, copper deficiencies have been identified in other Alaskan musk ox, which can result in compromised immune function. The Alaska Science Center is currently comparing levels of infection and trace mineral status between the affected population and a reference population exhibiting low mortality rates to evaluate relationships between disease and nutrition.

\section{Selected Publications}

Bowen, L., Miles, A.K., Murray, M., Haulena, M., Tuttle, J., Van Bonn, W. Adams, L., Bodkin, J.L., Ballachey, B., Estes, J., Tinker, M.T., Keister, R., and Stott, J.L., 2012, Gene transcription in sea otters (Enhydra lutris): Development of a diagnostic tool for sea otter and ecosystem Health, Molecular Ecology Resources, v. 12, p. 67-74. DOI: 10.1111/j.17550998.2011.03060.x.

Ely, C.R., Hall, J.S., Schmutz, J.A., Pearce, J.M., Terenzi, J.T., Sedinger, J.S. and Ip, H.S., 2013, Evidence that life history characteristics of wild birds influence infection rates and exposure to influenza A viruses: PLoS One, v. 8, e57614, DOI:10.1371/journal.pone.0057614.

Goldstein, T., Gill, V.A., Tuomi, P., Monson, D., Burdin, A., Conrad, P.A., Dunn, J.L., Field, C., Johnson, C., Jessup, D.A., Bodkin, J.L., and Doroff, A.M., 2011, Assessment of clinical pathology and pathogen exposure in sea otters (Enhydra lutris) bordering the threatened population in Alaska: Journal of Wildlife Diseases, v. 47, p. 579-592.

Handel, C.M., Pajot, L.M., Matsuoka, S.M., Van Hemert, C., Terenzi, J., Talbot, S.L., Mulcahy, D.M., Meteyer, C.U., and Trust, K.A., 2010, Epizootic of beak deformities among wild birds in Alaska-An emerging disease in North America?: The Auk, v. 127, p. 882-898. DOI: 10.1525/auk.2010.10111.

Kirk, C.M., Amstrup, S., Swor, R., Holcomb, D. and O’Hara, T.M., 2010, Hematology of southern Beaufort Sea polar bears (2005-2007)-Biomarker for an Arctic Ecosystem Health Sentinel: EcoHealth, v. 7, no. 3, p. 307-320. DOI: $10.1007 / \mathrm{s} 10393-010-0322-1$

Koehler, A.V., Pearce, J.M., Flint, P.L., Franson, J.C., and Ip, H.S., 2008, Genetic evidence of intercontinental movement of avian influenza by a migratory bird: The Northern Pintail (Anas acuta): Molecular Ecology, v. 17, p. 4754-4762. DOI: 10.1111/j.1365-294X.2008.03953.x.

Millen, H.T., Gonnering, J.C., Berg, R.K., Spencer, S.K., Jokela, W.E., Pearce, J.M., Borchardt, J.S. and Borchardt, M.A., 2012, Glass wool filters for concentrating waterborne viruses and agricultural zoonotic pathogens: Journal of Visualized Experiments, no. 61, e3930. DOI:10.3791/3930.

Pearce, J.M., Ramey, A.M., Flint, P.L., Koehler, A.V., Fleskes, J.P., Franson, J.C., Hall, J.S., Derksen, D.V. and Ip, H.S., 2009, Avian influenza at both ends of a migratory flyway - Characterizing viral genomic diversity to optimize surveillance plans for North America: Evolutionary Applications, v. 2, p. 457-468. DOI: 10.1111/j.1752-4571.2009.00071.x.

Pearce, J.M., Reeves, A.B., Ramey, A.M., Hupp, J.W., Ip, H.S., Bertram, M., Petrula, M.J., Scotton, B.D., Trust, K.A., Meixell, B., and Runstadler, J.A., 2011, Interspecific exchange of avian influenza virus genes in Alaska-The influence of trans-hemispheric migratory tendency and breeding ground sympatry: Molecular Ecology, v. 20, p. 1015-1025. DOI: 10.1111/j.1365294X.2010.04908.x.

Any use of trade, firm, or product names is for descriptive purposes only and does not imply endorsement by the U.S. Government.
Ramey, A.M., Ely, C.R., Schmutz, J.A., Pearce, J.M., and Heard, D.J., 2012, Molecular detection of hematozoa infections in Tundra Swans relative to migration patterns and ecological conditions at breeding grounds: PLoS One, v. 7, no. 9, e45789. DOI:10.1371/journal.pone.0045789.

Reeves, A.B, Pearce, J.M., Ramey, A.M., Meixell, B.W., and Runstadler, J.A., 2011, Interspecies transmission and limited persistence of low pathogenic avian influenza genomes among Alaska dabbling ducks: Infection, Genetics, and Evolution, v. 11, p. 2004-2010, DOI: 10.1016/j.meegid.2011.09.011.

Seo, H-J., Kim, H.C., Klein, T.A., Ramey, A.M., Lee, J-H., Kyung, S-G., Park, J-Y., Cho, Y.S., Cho, I-S., and Yeh, J-Y, 2013, Molecular detection and genotyping of Japanese encephalitis virus in mosquitoes during a 2010 outbreak in the Republic of Korea: PLoS One, v. 8, no. 2, e55165, DOI:10.1371/journal. pone. 0055165

Van Hemert, C., Armien, A.G., Blake, J.E., Handel, C.M., and O’Hara, T.M., 2013, Macroscopic, histologic, and ultrastructural lesions associated with avian keratin disorder in Black-capped Chickadees (Poecile atricapillus): Veterinary Pathology, v. 50, iss. 3, p. 500-513. DOI: 10.1177/0300985812469637.

Van Hemert, C., and Handel, C.M., 2010, Beak deformities in Northwestern Crows-Evidence of a multispecies epizootic: The Auk, v. 127, no. 4, p. 746-751. DOI: 10.1525/auk.2010.10132.

Van Hemert, C., Handel, C.M., and O'Hara, T.M., 2012, Evidence of accelerated beak growth associated with avian keratin disorder in Black-capped Chickadees (Poecile atricapillus): Journal of Wildlife Diseases, v. 48, p. 686-694.

White, J., Mirleau, P., Danchin, E., Mulard, H., Hatch, S.A., Heeb, P., and Wagner, R.H., 2010, Sexually transmitted bacteria affect female cloaca assemblages in a wild bird: Ecology Letters, v. 13, p. 1515-1524. DOI: 10.1111/j.1461-0248.2010.01542.x.

Yamaguchi, N., Hupp, J., Higuchi, H., Flint, P., and Pearce, J., 2010, Satellitetelemetry tracking of Northern Pintail Ducks Anas acuta during occurrences of the H5N1 virus in Japan: Implications for virus spread: Ibis, v. 152, p. 262-271. DOI: 10.1111/j.1474-919X.2010.01010.x.

Authors: Caroline Van Hemert, John Pearce, Karen Oakley, and Mary Whalen

\section{For Information Contact:}

U.S. Geological Survey

4210 University Dr., Anchorage, AK 99508

http://alaska.usgs.gov

Publishing support provided by the U.S. Geological Survey, Tacoma Publishing Service Center 